\title{
PENGEMBANGAN BUKU PENGAYAAN KIMIA BERBASIS KONTEKSTUAL PADA KONSEP ELEKTROKIMIA
}

\author{
Maried Ayuningtyas Oktavianie ${ }^{1}$, Dedi Irwandi ${ }^{\star *}$ dan Dewi Murniati ${ }^{1}$ \\ ${ }^{1}$ Pendidikan Kimia Fakultas IImu Tarbiyah dan Keguruan UIN Syarif Hidayatullah \\ Jl. Ir. H. Juanda No. 95 Ciputat Jakarta 15412 Indonesia \\ *E-mail: dedi.irwandi.yuskar@uinjkt.ac.id
}

\begin{abstract}
ABSTRAK
Penelitian ini bertujuan untuk mengembangkan buku pengayaan kimia berbasis kontekstual pada konsep elektrokimia dan mengetahui respon siswa terhadap buku tersebut. Proses pengembangan terdiri dari tiga tahap yaitu tahap perancangan, tahap produksi, dan tahap evaluasi. Pada tahap persiapan dihasilkan indikator buku pengayaan yang telah diintegrasikan dengan tujuh komponen kontekstual untuk dijadikan acuan dalam mengembangkan buku pengayaan. Pada tahap evaluasi produk dihasilkan buku pengayaan yang telah divalidasi oleh 4 orang ahli. Buku pengayaan diuji cobakan di kelas XII IPA I SMAN 18 Kabupaten Tangerang. Hasil uji coba terbatas mendapatkan skor respon siswa sebesar $82,49 \%$ termasuk dalam kategori layak dengan predikat baik.
\end{abstract}

Kata kunci: buku pengayaan, elektrokimia, kontekstual.

\begin{abstract}
The aims of the research were to develop a contextual based chemistry supplementary books on electrochemistry and to know the students' response about the book. The research was conducted in three steps namely planning phase, developing phase, and evaluating phase. In planning phase, the result of supplement book indicator was integrated with seven contextualcomponent to become a reference in developing the next supplement book. In evaluating phase, there were four experts who have been validated the data of supplement book. The supplement book was examined in XII IPA I class of SMAN 18 Kabupaten Tangerang. The result of limited trial of the students' response was $82.49 \%$ including to a proper category with good predicate.
\end{abstract}

Keyword: supplementary book, electrochemistry, contextual.

DOI: https://doi.org/10.15575/jtk.v3i1.2594 


\section{PENDAHULUAN}

Pelaksanaan sistem pendidikan di Indonesia berpedoman pada kurikulum. Kurikulum merupakan seperangkat rencana dan pengaturan mengenai tujuan, isi, dan bahan pelajaran serta cara yang digunakan sebagai pedoman penyelenggaraan kegiatan pembelajaran untuk mencapai tujuan pendidikan tertentu (PP RI No. 32, 2013:4). Kurikulum yang digunakan di Indonesia telah beberapa kali mengalami perubahan, hingga mencapai kurikulum 2013 yang saat ini diterapkan di sekolah. Perubahan ini berdampak pada perangkat belajar dan bukubuku yang digunakan guru dan siswa untuk menyesuaikan dengan kurikulum yang sedang digunakan.

Buku merupakan sarana yang penting dan strategis dalam upaya meningkatkan mutu pendidikan, sehingga pemerintah membuat kebijakan buku bagi siswa (Permendiknas RI No. 2, 2008:1). Buku sebagai salah satu sumber informasi disadari penting peranannya dalam proses pendidikan. Buku pelajaran merupakan semua buku yang dipakai dalam proses belajar dan pembelajaran (Sitepu, 2012:15). Dalam Permendiknas nomor 2 tahun 2008 pasal 1, ada berbagai jenis buku yang digunakan dalam pembelajaran, di antaranya yaitu buku teks pelajaran yang merupakan buku acuan yang wajib digunakan dalam satuan pendidikan (Permendiknas RI No. 2, 2008:2). Selain itu, Permendiknas nomor 2 tahun 2008 pasal 6 juga menyatakan bahwa selain buku teks pelajaran, pendidik dapat menggunakan buku panduan pendidik, buku pengayaan, dan buku referensi dalam proses pembelajaran (Permendiknas RI No. 2, 2008: 4). Berdasarkan Permendikbud RI nomor 65 tahun 2014, ada empat buku teks yang dianjurkan untuk digunakan di sekolah, yaitu buku teks yang dikeluarkan oleh Bumi Aksara, Tiga Serangkai Pustaka Mandiri, Wangsa Jatra Lestari, dan Yrama Widya (Permendikbud RI No. 65, 2014:6).

Masalah yang ada pada buku yang digunakan di sekolah adalah masih banyak buku yang menampilkan ilustrasi atau gambar hitam putih dan penggunaan tata bahasa yang sulit dipahami oleh peserta didik. Dengan bahan ajar yang monoton, siswa akan merasa bosan dan tidak tertarik untuk mengikuti pembelajaran, sehingga proses pembelajaran tidak efektif. Di sisi lain, masih banyak guru yang kesulitan dalam mengembangkan bahan ajar dan bergantung pada bahan ajar yang sudah tersedia, sedangkan kebutuhan siswa akan pengetahuan tidak cukup hanya bersumber pada buku teks saja (Zuriah, 2016:39-40).

Salah satu kendala yang membuat pendidik atau guru jarang membuat bahan ajar sendiri adalah guru tidak menguasai cara pembuatannya (Prastowo, 2011:49), sedangkan guru dituntut untuk mempunyai kemampuan mengembangkan bahan ajar sendiri. Selain itu, PP nomor 16 tahun 2007 menyebutkan bahwa guru harus memiliki kompetensi mengembangkan materi pelajaran yang kreatif (Permendiknas RI No. 16, 2007:22). Berdasarkan himbauan tersebut, jelas bahwasanya guru diharapkan mampu mengembangkan bahan ajar yang kreatif dalam pembelajaran. Oleh karena itu, diperlukan suatu inovasi bahan ajar yang mudah dipahami dengan penggunaan katakata sederhana tetapi tetap tidak mengesampingkan makna yang sesungguhnya, serta menampilkan ilustrasiilustrasi yang menarik, yang dapat memotivasi siswa untuk mempelajari lebih jauh tentang suatu materi pelajaran (Kurniasari, 2014:463).

Dalam pembelajaran, dibutuhkan banyak sumber agar pengetahuan anak berkembang, tidak hanya aspek kognitifnya tapi juga aplikasi dan penerapannya dalam kehidupan. Dalam Permendiknas nomor 2 tahun 2008 pasal 6 menyebutkan bahwa selain buku teks pelajaran, ada buku lain yang digunakan dalam pembelajaran, yaitu buku pengayaan (Permendiknas RI No. 2, 2008:4). Berdasarkan hasil wawancara dengan beberapa guru SMA di Kabupaten Tangerang, beberapa guru masih ada yang belum tahu tentang buku pengayaan dan ada yang mengira bahwa buku pengayaan adalah buku yang berisi latihan soal-soal. Buku pengayaan yaitu buku yang berisi materi yang lebih kaya 
dan biasa digunakan sebagai pendamping atau pelengkap buku teks utama (Permendiknas RI No. 2, 2008:2). Buku pengayaan tidak hanya untuk siswa namun dapat pula digunakan oleh pihak lain atau masyarakat pada umumnya (Pusat Perbukuan, 2008:8).

Buku pengayaan dibutuhkan untuk menambah kreativitas dan pengetahuan siswa. Guru dapat menyarankan pada para siswanya untuk menggunakan buku pengayaan agar menambah wawasan serta pengetahuan bagi siswa, karena buku pengayaan memberikan informasi yang lebih luas dan lebih dalam. Selain itu, buku pengayaan juga dapat mengembangkan kepribadian siswa, serta dapat membuat siswa lebih mandiri karena buku pengayaan mengandung informasi yang dapat mengasah keterampilan siswa agar lebih kreatif. Hal ini juga dikemukakan oleh Maryam (2012:49) dalam penelitiannya, yaitu buku pengayaan dapat memenuhi apa yang dibutuhkan oleh siswa, dalam arti bahwa buku pengayaan ini dapat mengembangkan kepribadian, memperluas pengetahuan, dan mengangkat keterampilan hidup yang bermanfaat dalam membangun kemandirian sosial siswa.

Buku pengayaan yang merupakan jenis dari buku nonteks memiliki kelebihan dibandingkan buku teks (Maryam, 2012:46). Perbedaan karakteristik keduanya dapat dilihat pada Tabel 1.

Tabel 1. Perbedaan Karakteristik Buku Teks dan Buku Pengayaan

\begin{tabular}{|l|l|l|l|}
\hline No. & Karakteristik & Buku Teks & $\begin{array}{l}\text { Buku } \\
\text { Pengayaan }\end{array}$ \\
\hline 1. & Target & $\begin{array}{l}\text { Terdiri dari } \\
\text { materi yang } \\
\text { ditulis dan } \\
\text { harus } \\
\text { dipahami } \\
\text { siswa dalam } \\
\text { satuan } \\
\text { pendidikan }\end{array}$ & $\begin{array}{l}\text { Menambah } \\
\text { pengetahuan } \\
\text { siswa dan } \\
\text { guru dalam } \\
\text { satuan } \\
\text { pendidikan }\end{array}$ \\
\hline 2. & $\begin{array}{l}\text { Kegunaan } \\
\text { dalam satuan } \\
\text { pendidikan }\end{array}$ & $\begin{array}{l}\text { Sumber } \\
\text { utama }\end{array}$ & $\begin{array}{l}\text { Bukan } \\
\text { sumber } \\
\text { utama, hanya } \\
\text { pelengkap }\end{array}$ \\
\hline
\end{tabular}

Tabel 1 menunjukkan bahwa buku pengayaan memiliki keunggulan dibandingkan buku teks pelajaran, diantaranya menambah pengetahuan guru dan siswa mengenai materi di luar buku teks.

Akhir-akhir ini upaya pengembangan buku pengayaan sudah banyak dilakukan. Misalnya, Pangastuti (2017:29) yang mengembangkan buku pengayaan kimia asam basa untuk peserta didik SMA/MA kelas 
XI berdasarkan kurikulum 2013 yang dinyatakan valid dan memenuhi kriteria materi, penyajian, bahasa, dan grafika dengan persentase keidealan sebesar $84,5 \%$ yang menunjukkan bahwa buku pengayaan layak digunakan sebagai sumber belajar mandiri bagi peserta didik dengan kategori sangat baik. Namun, diperlukan inovasi untuk mengembangkan buku pengayaan kimia yang mengintegrasikan pembelajaran kontekstual.

Salah satu disiplin ilmu dalam ruang lingkup IPA adalah ilmu kimia yang memiliki hubungan yang sangat erat dengan kehidupan manusia dan berperan penting di antara ilmu pengetahuan lainnya (Suharyadi dkk., 2013:61). Pembelajaran kimia cenderung lebih menekankan pada pengetahuan sains murni. Materi yang ada dalam pelajaran kimia cukup sulit untuk dipahami siswa, salah satunya adalah elektrokimia. Materi elektrokimia berisi tentang konsep listrik dan reaksi reduksi oksidasi. Hal ini juga dikemukakan oleh Karsli \& Calik (2012:485) dalam jurnalnya yang menyatakan bahwa, elektrokimia merupakan materi yang paling sulit diajarkan dan dipahami oleh guru dan siswa di antara materi lain yang ada dalam buku literatur kimia, seperti kesetimbangan kimia, struktur materi, asam dan basa, termokimia, dan sebagainya. Hal ini dikarenakan materi kimia memiliki banyak konsep-konsep abstrak. Selain itu, kebanyakan guru hanya mengajarkan reaksi redoks pada sel elektrokimia sederhana untuk menjelaskan transfer elektron dan sel elektrokimia, sedangkan penggunaan sel elektrokimia modern dalam kehidupan nyata sangat jarang dibahas karena dianggap terlalu sulit bagi siswa (Markic \& Eilks, 2006:254). Oleh karena itu, diperlukan pembelajaran yang sesuai, yakni dengan menghubungkan apa yang siswa pelajari dengan kehidupan sehari-hari, sehingga siswa dapat mempelajari ilmu kimia dengan baik.

Pembelajaran yang sesuai agar siswa mampu mengaitkan apa yang mereka pelajari dengan kehidupan adalah pembelajaran kontekstual. Pembelajaran kontekstual merupakan suatu konsep belajar yang mendorong siswa untuk dapat mengetahui hubungan antara pengetahuan yang dimiliki dengan pemanfaatannya dalam dunia sekitarnya, baik untuk diri sendiri, keluarga maupun masyarakat (Rosalin, 2008:27). Siswa diharapkan dapat mendapatkan pembelajaran yang bermakna dengan menggunakan pembelajaran kontekstual ini, karena pengetahuan tidak hanya ditransfer oleh guru ke siswa, tetapi siswa mengalami dan bekerja dalam proses belajarnya, sehingga siswa dapat mengkonstruk pengetahuannya sendiri.

Menurut Rusman (2011:193-197) ada tujuh komponen dalam pembelajaran kontekstual, yaitu:

1) Konstruktivisme; konstruktivisme merupakan landasan berpikir dalam pembelajran kontekstual. Siswa ditekankan untuk menghubungkan antara setiap konsep dengan kenyataan.

2) Inkuiri; inti dari pembelaaran kontekstual adalah menemukan (inkuiri). Keterampilan dan pengetahuan yang diperoleh oleh siswa diharapkan hasil dari menemukan sendiri, bukan hasil mengingat seperangkat fakta-fakta (Trianto, 2011:114).

3) Bertanya; pertanyaan diajukan untuk mencari dan menemukan kaitan antara konsep yang dipelajari dalam kaitannya dengan kehidupan nyata.

4) Masyarakat belajar; maksud dari masyarakat belajar adalah membiasakan siswa untuk melakukan kerjasama dan memanfaatkan sumber belajar dari temanteman belajarnya.

5) Pemodelan; pemodelan merupakan komponen yang menunjukkan model yang bisa digunakan sebagai rujukan atau panutan siswa dalam bentuk penampilan tokoh, penampilan hasil karya, demonstrasi kegiatan, cara mengoperasi sesuatu, dan sebagainya (Muslich, 2009:43).

6) Refleksi; refleksi mejadi bagian penting dalam pembelajaran kontekstual, karena melalui refleksi siswa dapat mengevaluasi hal-hal yang telah dipelajari serta 
memperbarui pengetahuan yang telah dibentuk.

7) Penilaian sebenarnya; penilaian sebenarnya memberikan kesempatan pada siswa untuk dapat mengembangkan penilaian diri dan penilaian sesama.

Berdasarkan uraian di atas, penulis merasa perlu adanya inovasi untuk mengembangkan buku pengayaan kimia yang mengintegrasikan pembelajaran kontekstual agar siswa mampu menghubungkan pengetahuan konsep-konsep atau fakta-fakta yang didapat di sekolah dengan kehidupan sehari-hari.

\section{METODE PENELITIAN}

Penelitian pengembangan ini dilaksanakan di SMA Negeri 18 Kabupaten Tangerang di kelas XII IPA 1 pada tahun ajaran 2015/2016. Proses perancangan sampai evaluasi dilakukan pada bulan Mei 2015-Mei 2016.

Jenis penelitian yang dilakukan merupakan penelitian pengembangan. Metode yang digunakan dalam penelitian ini adalah metode deskriptif. Peneliti memberikan pemaparan secara naratif mengenai hal yang diteliti, dan data yang didapat dijabarkan dalam bentuk kualitatif dan bukan berupa angka-angka statistik (Margono, 2013:39). Adapun tahapan-tahapan penelitian yang dilakukan pada penelitan ini menggunakan tahapan yang dikemukakan oleh Warsita (2008:226227) yang terdiri dari tiga tahap, yaitu tahap perancangan, tahap produksi, dan tahap evaluasi. Tahapan ini menghasilkan produk penelitian yang dapat digunakan untuk mengembangkan mutu pendidikan dan pembelajaran secara efektif.

Objek pada penelitian ini adalah buku pengayaan kimia berbasis kontekstual pada konsep elektrokimia. Subjek penelitian yaitu tiga orang dosen kimia, satu orang guru kimia, dan 33 orang siswa kelas XII IPA 1 SMA Negeri 18 Kabupaten Tangerang.

Instrumen yang digunakan dalam penelitian ini berupa pedoman wawancara, lembar validasi, dan lembar angket respon siswa. Data lembar validasi dihitung menggunakan skala Guttman, sedangkan data angket respon siswa dianalisis menggunakan skala Likert. Analisis data dilakukan dengan mendeskripsikan setiap hal yang dilakukan dalam penelitian dalam bentuk uraian naratif. Data yang diperoleh dari hasil validasi dan angket respon siswa masing-masing ditentukan persentasenya menggunakan rumus berikut:

Persentase $=\frac{\text { skor total }}{\text { skor maksimal }} \times 100 \%$

Analisis data dilakukan dengan menyederhanakan data ke dalam bentuk yang lebih mudah dibaca agar data yang telah terkumpul dapat dianalisis dan diambil kesimpulan mengenai pengembangan buku pengayaan kimia berbasis kontekstual pada konsep elektrokimia ini sangat baik, baik, cukup, kurang, atau sangat kurang. Kriteria interpretasi skor dapat dilihat pada Tabel 2. (Riduwan \& Sunarto, 2010:41).

Tabel 2. Kriteria Intrepretasi Skor

\begin{tabular}{|c|c|c|}
\hline No. & Interval Skor & Kategori \\
\hline 1. & $81-100 \%$ & Sangat Baik \\
\hline 2. & $61-80 \%$ & Baik \\
\hline 3. & $41-60 \%$ & Cukup \\
\hline 4. & $21-40 \%$ & Kurang \\
\hline 5. & $0-20 \%$ & Sangat Kurang \\
\hline
\end{tabular}

\section{HASIL DAN PEMBAHASAN}

Tahap perancangan terdiri dari dua langkah, yaitu analisis kebutuhan dan penyusunan Garis Besar Isi Media (GBIM) dan jabaran Materi (JM). Analisis kebutuhan dilakukan untuk mengetahui kesenjangan antara harapan dan kenyataan yang terjadi di lapangan. Analisis kebutuhan pada penelitian ini dilakukan melalui wawancara kepada tiga orang guru mata pelajaran kimia dari sekolah yang berbeda. Wawancara yang dilakukan terkait dengan ketersediaan buku pengayaan di sekolah dan kebutuhan penggunaan buku pengayaan oleh guru. Dari hasil wawancara 
didapatkan bahwa guru masih menggunakan buku paket/buku teks yang dijual di pasaran dalam pembelajaran di sekolah. Di samping itu guru juga menggunakan Lembar Kerja Siswa (LKS) dan materi dari internet sebagai pelengkap buku teks. Kemudian pada langkah penyusunan GBIM terbagi lagi menjadi dua langkah, yakni pemilihan materi, dan penentuan indikator materi buku pengayaan.

Setelah melakukan analisis kebutuhan, peneliti menentukan materi yang akan dibuat dalam bentuk buku pengayaan kimia. Materi yang dipilih adalah elektrokimia yang akan dikembangkan ke dalam buku pengayaan, yakni memperdalam materi mengenai aplikasi elektrokimia dalam kehidupan sehari-hari. Pada buku-buku teks kimia, materi elektrokimia lebih berfokus pada penyetaraan reaksi reduksi dan oksidasi, sedangkan untuk aplikasi dalam kehidupan sehari-hari masih sedikit dibahas dan terbatas pada penggunaan baterai dan aki secara umum. Dengan demikian, materi elektrokimia dianggap sesuai jika dibuat ke dalam buku pengayaan kimia berbasis kontekstual yang akan dikembangkan, karena materi elektrokimia dapat diaplikasikan ke dalam kehidupan sehari-hari.

Indikator buku pengayaan ditetapkan berdasarkan tujuan pembelajaran umum (kompetensi dasar) dan tujuan pembelajaran khusus (indikator keberhasilan). Tujuan umum memuat tujuan secara umum yang diharapkan dapat menutupi kesenjangan dari hasil analisis kebutuhan. Sedangkan tujuan khusus merupakan uraian dari tujuan umum. Kemudian tujuan khusus ini diuraikan kembali menjadi indikator buku pengayaan.
Tahap produksi dikelompokkan menjadi tiga sub tahapan, yaitu persiapan, pelaksanaan, dan penyelesaian. Dalam tahap persiapan dilakukan penentuan desain buku pengayaan, seperti pemilihan ukuran kertas, orientasi kertas, margin yang digunakan, jenis huruf, serta ukuran huruf. Selain itu dalam tahap ini juga dilaksanakan pengumpulan materi buku pengayaan yang akan dimuat ke dalam buku pengayaan kimia. Dalam tahap pelaksanaan, kegiatan yang dilakukan adalah mengembangkan produk awal buku pengayaan kimia berbasis kontekstual dari hasil analisis indikator buku pengayaan yang telah dibuat dan dikaitkan dengan desain buku yang telah ditentukan sebelumnya. Struktur buku pengayaan terdiri dari tiga bagian, yaitu bagian awal, isi, dan akhir. Selain membuat buku pengayaan, pada tahap ini juga dibuat instrumen lembar validasi dan angket respon siswa. Perbaikan buku meliputi konten, tata letak, dan bahasa yang digunakan sehingga menghasilkan beberapa perubahan.

Tahap evaluasi terdiri dari dua subtahapan, yaitu evaluasi pramaster dan uji coba lapangan. Tahap evaluasi dilakukan untuk mengetahui respon siswa mengenai buku pengayaan yang telah dikembangkan serta untuk mengetahui kelayakan buku pengayaan kimia berbasis kontekstual pada konsep elektrokimia sebagai buku pendamping yang mampu menambah wawasan kepada pembaca. Tahap evaluasi buku pengayaan ini dilakukan dengan uji coba terbatas kepada 33 siswa SMAN 18 Kabupaten Tangerang dengan pengisian angket respon siswa setelah membaca buku tersebut. Hasil rekapitulasi angket respon siswa dapat dilihat pada Gambar 1. 


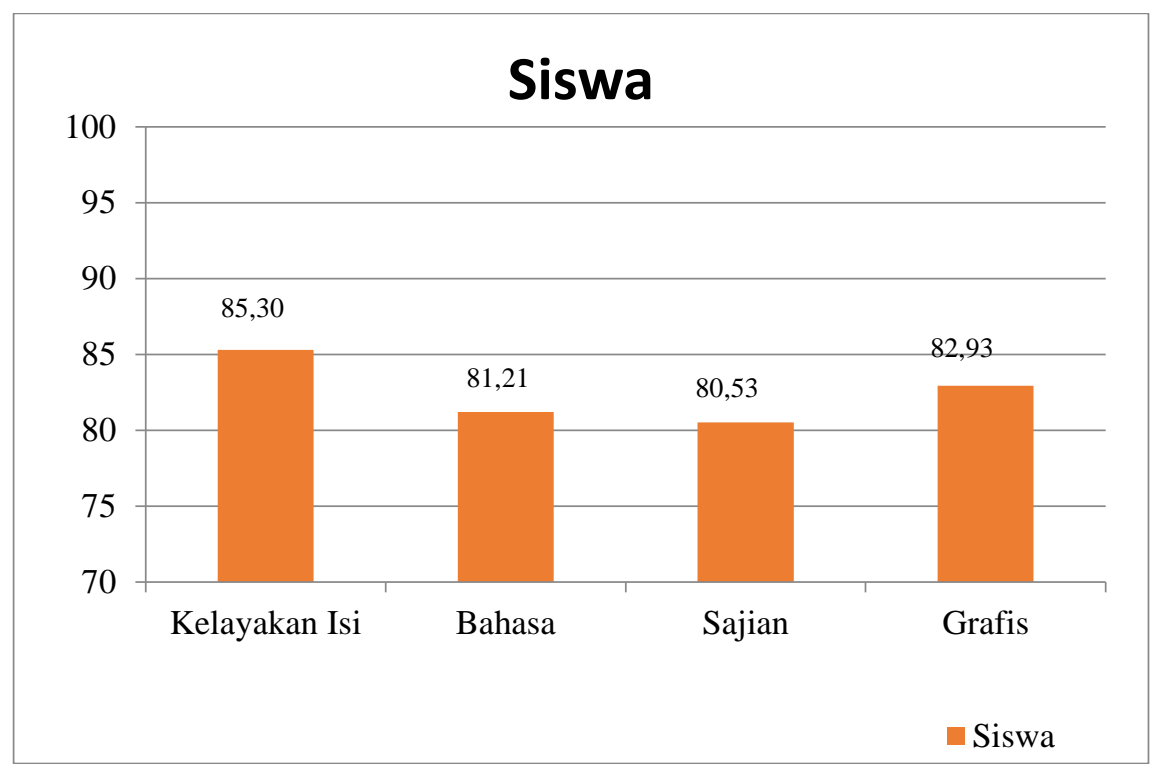

Gambar 1. Persentase Rata-rata Tiap Aspek

Berdasarkan Gambar 1 dapat dilihat bahwa persentase rata-rata angket tiap aspek pada siswa menunjukkan hasil yang tidak jauh berbeda, untuk aspek kelayakan isi $85,30 \%$, aspek bahasa $81,21 \%$, aspek sajian $80,53 \%$, dan aspek grafis $82,93 \%$. Data hasil persentase respon siswa diperoleh skor akhir sebesar $82,49 \%$ termasuk kategori layak dengan predikat sangat baik.

Pada aspek kelayakan isi memenuhi kriteria layak dengan predikat sangat baik dengan rata-rata aspek sebesar 85,30\% karena sebagian besar siswa berpendapat bahwa materi yang terdapat dalam buku pengayaan kimia yang telah dikembangkan memiliki manfaat untuk menambah wawasan untuknya. Hal ini sesuai dengan pengertian buku pengayaan menurut Pusat Perbukuan (2008:8), yaitu buku yang dimaksudkan untuk memperkaya wawasan, pengalaman, dan pengetahuan pembacanya. Selain itu, buku pengayaan kimia yang dikembangkan sesuai dengan peristiwa atau aplikasi yang ada di lingkungan sekitarnya. Hal ini sejalan dengan konsep pembelajaran kontekstual menurut Rosalin (2008:27) yaitu konsep belajar yang membantu guru mengaitkan antara materi yang diajarkan dan situasi dunia nyata siswa dengan mendorong siswa membuat hubungan antara pengetahuan yang dimilikinya dengan penerapannya dalam kehidupan mereka sebagai anggota keluarga dan masyarakat.

Kelayakan buku pengayaan berdasarkan respon siswa juga didapatkan melalui aspek grafis sebesar $82,93 \%$. Hasil respon siswa menunjukkan bahwa desain buku pengayaan kimia yang dikembangkan menarik untuk dipelajari karena ilustrasi, grafis, gambar, dan foto yang ditunjukkan dalam buku pengayaan sangat baik. Hal ini sesuai dengan peranan ilustrasi dalam buku pelajaran yaitu menarik dan mengarahkan perhatian, serta membantu siswa memahami konsep yang sulit dijelaskan dengan kata-kata (Sitepu, 2012:151).

Pada aspek bahasa didapatkan persentase rata-rata sebesar $81,21 \%$. Hal ini menandakan bahwa bahasa yang digunakan dalam buku pengayaan mudah dipahami, karena istilah yang digunakan sesuai dengan pokok bahasan dengan bahasa yang mudah dimengerti oleh pembaca. Selain itu, penggunaan bahasa dalam buku sesuai dengan EYD. Jannah dkk. (2013:177) dalam penelitiannya menyatakan bahwa kategori layak pada aspek bahasa didapatkan karena bahasa yang digunakan dalam buku yang dikembangkan merupakan bahasa yang baik dan benar sesuai dengan kaidah bahasa Indonesia yang baku. Penulisan bahasa tidak menggunakan bahasa daerah, sehingga 
dapat dipahami semua siswa dari berbagai daerah.

Pada aspek sajian didapatkan skor rata-rata sebesar $80,53 \%$. Buku pengayaan sangat baik dalam memotivasi dan meningkatkan minat belajar serta mendorong rasa ingin tahu dari pembaca. Sejalan dengan penelitian yang dilakukan oleh Purnomo (2014:65) bahwa hal ini dikarenakan buku pengayaan ini mengintegrasikan tujuh komponen kontekstual, salah satunya adalah konstruktivisme, sehingga dalam buku pengayaan mengandung pertanyaanpertanyaan yang mengkonstruk dan merangsang siswa untuk mempelajarinya lebih dalam. Contoh komponen konstruktivisme dalam buku pengayaan dapat dilihat pada Gambar 2.

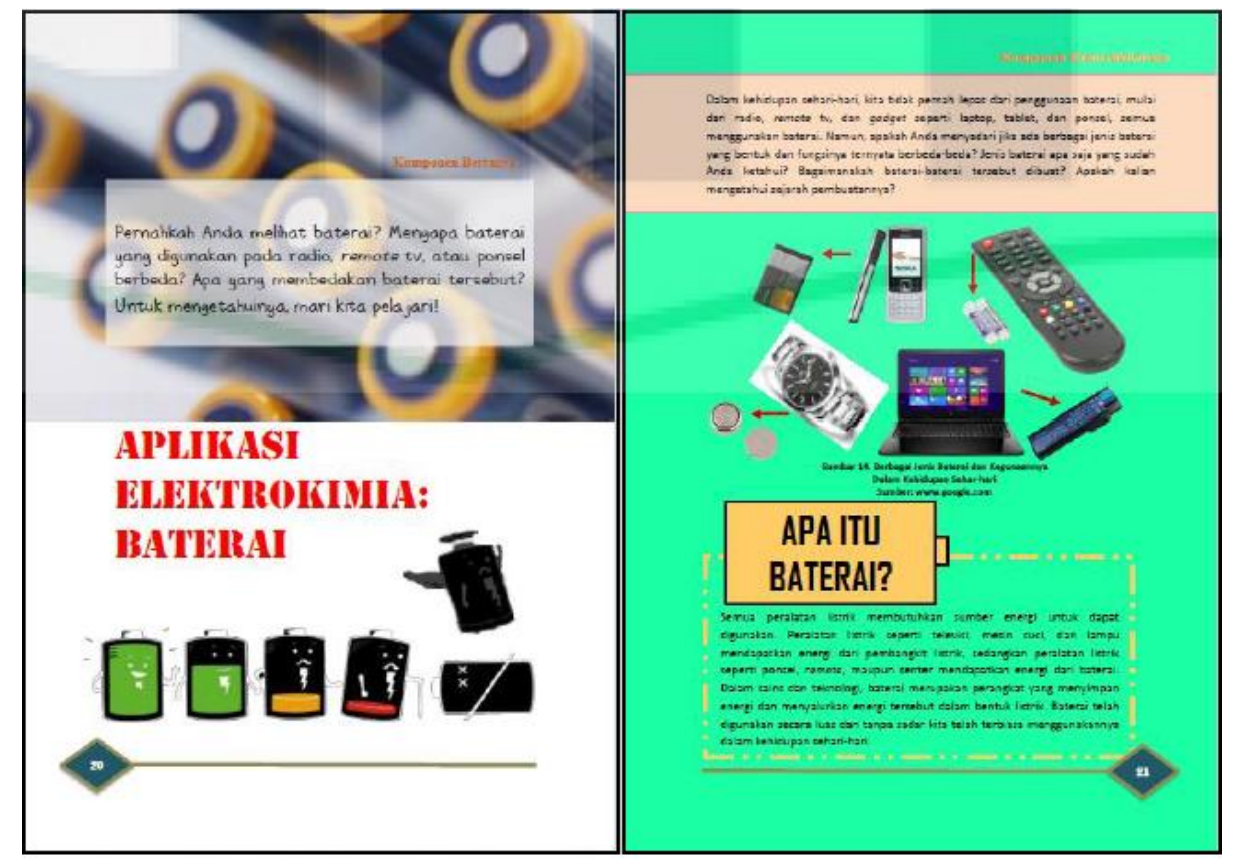

Gambar 2. Contoh Komponen Konstruktivisme

Selain itu di akhir pokok bahasan diberikan renungan berdasarkan kejadian yang ada dalam kehidupan sehari-hari dan dikaitkan dengan cuplikan ayat Al-Qur'an yang dapat membuat siswa termotivasi.

\section{KESIMPULAN}

Penelitian ini menghasilkan buku pengayaan kimia berbasis kontekstual pada konsep elektrokimia yang dikembangkan melalui tiga tahap, yaitu: (1) tahap perancangan dilakukan dengan analisis kebutuhan dengan wawancara guru, penyusunan garis besar isi media dan jabaran materi (pemilihan materi dan penentuan indikator buku pengayaan);
(2) tahap produksi dilakukan dengan penentuan desain buku dan mengumpulkan materi elektrokimia, pengembangan buku serta instrumen validasi dan angket, hingga menghasilkan buku pengayaan kimia berbasis kontekstual; (3) tahap evaluasi dilakukan dengan validasi ahli dan uji coba lapangan, sehingga diperoleh data respon siswa terhadap buku pengayaan kimia berbasis kontekstual pada konsep elektrokimia yang telah dibuat memenuhi kriteria sangat baik dengan persentase rata-rata $82,49 \%$ dari setiap aspek, dengan rincian untuk aspek kelayakan isi $85,30 \%$, aspek bahasa $81,21 \%$, aspek sajian $80,53 \%$, dan aspek grafis $82,93 \%$. 


\section{DAFTAR PUSTAKA}

Jannah, D. F., \& Dwiningsih, K. (2013). Kelayakan Buku Ajar Kimia Berorientasi Quantum Learning pada Materi Kimia Unsur untuk Kelas XII SMA. Unesa Journal of Chemical Education, 2, 163170.

Karsli, F \& Calik, M. (2012). Can Freshman Science Student Teachers' Alternative Conceptions of 'Electrochemical Cells' Be Fully Diminished?. Asian Journal of Chemistry, 24(2), 485-491.

Kurniasari, Dwi A. (2014). Pengembangan Buku Suplemen IPA Terpadu dengan Tema Pendengaran Kelas VII. Unnes Science Educational Journal, 3(2), 462467.

Margono. (2013). Metodologi Penelitian Pendidikan. Jakarta: Rineka Cipta.

Markic, S \& Eilks, I. (2006). Cooperative and Context-based Learning on Electrochemical Cells in Lower Secondary Chemistry: A Project of Participatory Action Research. Science Educatio International, 17(4), 253-273.

Maryam, S. (2012). Strenghtening the Character: Uphold Ethics in Indonesian Language Study Pass by Supplementary Books. International Journal for Educational Studies, 39-50.

Muslich, M. (2009). KTSP Pembelajaran Berbasis Kompetensi dan Kontekstual. Jakarta: PT. Bumi Aksara.

Pangastuti, Ratri P. (2017). Pengembangan Buku Pengayaan Kimia Asam Basa untuk Peserta Didik SMA/MA Kelas XI Berdasarkan Kurikulum 2013. Jurnal Pembelajaran Kimia, 6(1), 23-30.

Peraturan Menteri Pendidikan Dan Kebudayaan Republik Indonesia Nomor 65 Tahun 2014. (2014). Buku Teks Pelajaran dan Buku Panduan Guru Kurikulum 2013 Kelompok Peminatan
Pendidikan Menengah yang Memenuhi Syarat Kelayakan untuk Digunakan dalam Pembelajaran. Jakarta: Menteri Pendidikan Nasional.

Peraturan Menteri Pendidikan Nasional Republik Indonesia Nomor 16 Tahun 2007. (2007). Standar Kualifikasi Akademik dan Kompetensi Guru. Jakarta: Menteri Pendidikan Nasional.

Peraturan Menteri Pendidikan Nasional Republik Indonesia Nomor 2 Tahun 2008. (2008). Buku. Jakarta: Departemen Pendidikan Nasional.

Peraturan Pemerintah Republik Indonesia Nomor 32 Tahun 2013. (2013). Perubahan Atas Peraturan Pemerintah Nomor 19 Tahun 2005 tentang Standar Nasional Pendidikan. Jakarta: Kementerian Sekretariat Negara Republik Indonesia.

Prastowo, A. (2010). Panduan Kreatif Membuat Bahan Ajar Inovatif. Yogyakarta: Diva Press.

Purnomo, S. (2014). Pengembangan Buku Suplemen Kimia Berbasis Kontekstual pada Konsep Larutan Asam Basa. Skripsi. Universitas Islam Negeri Syarif Hidayatullah, Jakarta.

Pusat Perbukuan. (2008). Pedoman Penulisan Buku Nonteks Pelajaran. Jakarta: Departemen Pendidikan Nasional.

Riduwan \& Sunarto. (2010). Dasar-dasar Statistika. Bandung: Alfabeta.

Rosalin, E. (2008). Gagasan Merancang Pembelajaran Kontekstual. Bandung: PT. Karsa Mandiri Persada.

Rusman. (2010). Model-model Pembelajaran: Mengembangkan Profesionalisme Guru. Jakarta: PT. Rajagrafindo Persada. 
Sitepu, B. P. (2012). Penulisan Buku Teks Pelajaran. Bandung: PT. Remaja Rosdakarya.

Suharyadi, Permanasari, A., \& Hernani. (2013). Pengembangan Buku Ajar Berbasis Kontekstual pada Pokok Bahasan Asam dan Basa. Jurnal Riset dan Praktik Pendidikan Kimia, 1(1), 6068.

Trianto. (2011). Mendesain Model Pembelajaran Inovatif-Progresif: Konsep, Landasan, dan Implementasinya pada Kurikulum Tingkat Satuan Pendidikan (KTSP). Jakarta: Kencana Prenada Media Group.

Warsita, B. (2008). Teknologi Pembelajaran: Landasan dan Aplikasinya. Jakarta: PT. Rineka Cipta.

Zuriah, N., Sunaryo, H., Yusuf, N.. (2016). IbM Guru dalam Pengembangan Bahan Ajar Kreatif Inovatif berbasis Potensi Lokal. Jurnal Dedikasi, 13, 39-49. 